not known whether resistance to both drugs developed simultaneously, as in the case of the sulphadiazineresistant strains $A$ and $B$, or whether resistance to sulphadiazine developed only after prolonged treatment with 'Paludrine'. That the latter alternative is the more probable is shown by the following observations. The untreated parent strain of $\boldsymbol{P}$. gallinaceum was tested with $1 \cdot 25 \mathrm{mgm}$. doses of sulphadiazine and found to have a normal sensitivity to this compound. A substrain was then passaged at intervals of two to three days through chicks treated with doses of 'Paludrine' increasing from 0.025 to $0.2 \mathrm{mgm}$. After ten weeks treatment the strain was proved to be resistant to $0.5 \mathrm{mgm}$. doses of 'Paludrine', a dose greater than that with which it had been treated previously, but its sensitivity to the minimum effective dose of sulphadiazine was unchanged. In this strain, therefore, the development of resistance to 'Paludrine' was not accompanied by resistance to sulphadiazine. The strain is being treated further with larger doses of 'Paludrine' in order to discover if, and when, sulphadiazine-resistance develops. The fact that sulphadiazine-resistance did not develop simultaneously with resistance to 'Paludrine' in 'Paludrine'-treated birds, but only appeared in a strain subjected to prolonged treatment with the maximum tolerated dose of 'Paludrine', would explain the failure of Williamson and his co-workers ${ }^{2,6}$ to observe resistance to sulphadiazine when their 'Paludrine'-resistant strain was treated with this drug, as their strain had been subjected to 'Paludrine' for a much shorter period than had ours.

Williamson and his co-workers ${ }^{2}$ suggest that the presence or absence of a pyrimidine ring in such compounds as 3349

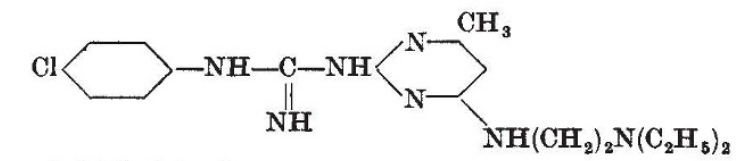

and 'Paludrine'

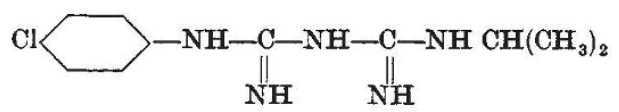

may be a factor in determining drug-resistance. Sulphadiazine,<smiles>NC1CCC(S(=O)(=O)NC2NCCCN2)CC1</smiles>

however, also contains a pyrimidine ring, and we have now shown that it, like 'Paludrine', forms drugresistant strains of $P$. gallinaceum and that resistance between it and 'Paludrine' is reciprocal. On the other hand, Williamson and his co-workers ${ }^{2}$ failed to produce resistance to 3349 , which has a pyrimidine ring. In these compounds, therefore, the presence or absence of the pyrimidine ring does not appear to determine the formation of drug-resistant strains of $P$. gallinaceum.

It has been shown by Maier and Riley in $P$. gallinaceum and by Marshall and his co-workers ${ }^{8}$ in $P$. lophurce that the antimalarial action of sulphonamides is inhibited by para-aminobenzoic acid. We have confirmed this observation on our strain of $P$. gallinaceum; but preliminary experiments suggest that the action of 'Paludrine' is not antagonized by this compound. The demonstration of cross-resistance between 'Paludrine' and sulphadiazine, two com- pounds of great importance therapeutically, presents a very interesting problem regarding the mechanism of their antimalarial action.

The work has been financed by the Medical Research Council. We are indebted to the Imperial Chemical (Pharmaceuticals), Ltd., for the 'Paludrine' and to Messrs. May and Baker, Ltd., for the sulphonamides.

'Bishop, A., and Birkett, B., Nature, 159, 884 (1947).

${ }^{2}$ Williamson, J., Bertram, D. S., and Lourie, E. M., Nature, 159, 885 (1947).

S Knoppers, A. T., Nature, 160, 606 (1947).

- Bishop, A., and Birkett, B., Parasitology, 39, 125 (1948).

5 Emerson, S., and Cushing, J. E., Fed. Proc., 5, 379 (1946).

${ }^{6}$ Williamson, J., and Lourie, E. M., Ann. Trop. Med. and Parasit., 41, $278(1947)$

${ }^{7}$ Maier, J., and Riley, E., Proc. Soc. Exp. Biol. Med., 50, 152 (1942). - Marshall, jun., E. K., Litchfleld, J.T., and White, H. J., J. Pharmacol., 75, 89 (1942).

\section{CHANGING ASPECTS OF NUTRITION}

GECTION I (Physiology) of the British Association $D$ devoted the morning session on September 9 to a discussion of "The Changing Aspects of Nutrition". Prof. J. R. Marrack introduced the subject with a review of work done on the relation of nutrition to infection. He pointed out that we are uncertain which nutrients are particularly involved in defence against infection and how the defences are weakened by malnutrition, particularly in human beings. In experimental animals deprived of vitamin A the ciliated columnar epithelium of the respiratory passages undergoes keratinizing metaplasia. Bacteria that get into the passages are not cleared out by cilia, and the passages are blocked by desquamated cells. In consequence the animals are liable to get broncho-pneumonia. It is not known how frequently this keratinizing metaplasia occurs in the respiratory passages of human beings. When it is found, the nutritionist ascribes it to lack of vitamin $A$, whereas the morbid anatomist thinks that it is caused by inflammation or irritation.

In the discussion, Dr. H. M. Sinclair said that he had seen bronchiectasis in Holland, which was attributed to lack of vitamin $\mathrm{A}$. In experiments in which human beings have been deprived of vitamin $A$ for more than a year, the subjects were not abnormally liable to respiratory infections ; nor do large supplements of vitamin A appear to reduce the frequency or severity of colds.

Cannon and his school have found that the forma. tion of antibodies is impaired in animals that are severely depleted of protein. Gell has recently shown that very ill-nourished Germans formed less antibodies in response to injections of antigens than were formed by well-fed British soldiers. But protein is not the only nutrient that is involved in the formation of antibodies, and other defences are impaired in malnourished animals.

Prof. Marrack suggested that the infecting organ. isms of those diseases, to which resistance seems to be increased by malnutrition, are exacting organisms that invade the cells of the host. When the host lacks some nutrient, such as vitamin $\mathrm{B}_{1}$, the metabolism of the host's cells may be so altered that they are no longer congenial to the invader.

Dr. J. W. Howie described experiments designed to show the effects of the less-severe degrees of malnutrition. The number of eggs of parasitic worms was counted in the fæces of a group of ewes fed on 
pasture and of another group that were given a protein rice concentrate. After a year there were much fewer eggs in the fæces of the group that were given the concentrate. One group of Swiss white mice were given a stock diet and another diet that supplied more protein and calcium. Suspensions of human tubercle bacilli were injected intravenously. In the group that had the higher protein ration, the mean survival time was longer and the extent of invasion of the lungs less than in the group that had the stock diet.

Prof. A. Fleisch discussed the effect of rationing in Switzerland as a large-scale experiment on human requirements. Up to 1943 , when rations supplied little more than 2,000 calories a day to a normal adult, health improved, there was less dental caries and weights were maintained. During the period of rationing the amounts of meat in the diet fell and the amounts of potatoes and vegetables rose; the amounts of calcium, niacine, vitamin $B_{1}$, and ascorbic acid in the diets were considerably higher than before. When the number of calories fell below 2,000 in 1944 and 1945, weights of adults and children fell, and the hæmoglobin level of a sample group, which was studied over the whole period, fell. Prof. Fleisch thought that the League of Nations standard of requirements for a sedentary adult is unnecessarily high.

Dr. B. S. Platt discussed practical applications of the knowledge of nutrition and the social aspects of nutrition in villages of Central and West Africa. The estimated expenditure of energy was low and approximately equal to consumption. The yields of food crops were low and would barely supply the calories required. In West Africa nutrition suffered more, as groundnuts were grown for sale, and less food could be grown for home consumption. Much time was lost in collecting and preparing food and in drawing water. The problem is to build a new social structure in place of the native structure which is breaking down.

\section{INTERNATIONAL COMMISSION ON LARGE DAMS}

\section{CONGRESS IN SWEDEN}

$\mathrm{T}$ HE third Congress of the International Commission on Large Dams was held in Sweden during June 10-17. The opening session was held in the Stockholm Concert Hall (Konserthuset) and the closing session at the Saga Cinema, Trollhättan. At the opening session Mr. G. Westerburg, president of the Swedish Committee of the International Commission on Large Dams, welcomed the delegates from twenty-three nations, and M. A. Coyne, president of the Commission, declared the Congress open.

There were four plenary sessions dealing with the following technical questions :

(1) Critical exposition of the measurement of uplift pressures and stresses arising therefrom; M. W. Schurter, Inspecteur fédéral et chef des Travaux Publics de la Confédération Suisse, acting as general reporter.

(2) Research methods and instruments for the measurement of stresses and deformation in earth and concrete dams; M. Mary, ingenieur en chef des Ponts et Chaussées, France, acting as general reporter.

(3) The most recent precautions to avoid the formation of pipings; Prof. K. Terzaghi of Harvard
University, Cambridge, Mass., acting as general reporter.

(4) Experiences arising from the testing and the actual use of special cements for large dams; Prof. B. Hellström, of the Royal Institute of Technology, Stockholm, acting as general reporter.

More than seventy papers ranging over these subjects were presented for discussion, and most of these were available before the meeting and were accompanied by summaries in French and English.

The question of upward water pressure on dams, and what allowances should be made for it, is a problem which has worried designers of new dams for a great many years. The information needed is not only the value per unit surface area of the upward pressure to be allowed in calculations, but also some idea of the extent of the area of the dam over which such upward pressure operates. Of the eleven papers submitted, three, by Harza (U.S.A.), Leliavsky Bey (Egypt) and MeHenry (U.S.A.), dealt with the scientific aspects of the problem and arrived at the general conclusion that, within the limits of error of measurement, the upward pressures act on practically the whole geometrical surface in question, whatever their specific values at particular points, whether in a plane intersecting the dam, or in the plane of the foundation. Seven other papers dealt with uplift pressures from the practical point of view, five describing the experimental determination of uplift pressures in existing structures, and two dealing with the influence such pressures have on the design of masonry or concrete dams, particularly with regard to the stresses induced. On the upstream side, the value of the specific upward pressure is equal to the hydrostatic pressure of the water in the reservoir, while on the downstream side it is normally zero. Between these two extreme edges of the crosssection, the uplift pressure varies generally in a linear manner, allowing, of course, for the effect of any structural measures designed to reduce the intensity of the pressure. Needless to say, appropriate structural measures should be adopted to prevent the upward pressures becoming operative in the base of the dam, on the foundation surface, or in the body of the dam itself. The remaining paper in this group, presented by Prof. Myslivec, of Prague, dealt with the important problem of infiltration through earthwork embank. ments, and with the properties of suitable sealing materials for these.

Nineteen papers were submitted on the second question dealing with research methods and instrumentation. They ranged over many and varied topics such as the measurement of displacements of the soil and of earthworks, the measurement of the pressure of water contained in earthworks, tempera. ture and shrinkage measurements, the deformation of gravity dams and arch dams, and the settlement of earth and rock fills. The reports also provided a use. ful comparison of the experimental methods and measuring equipment used in different countries. Of particular interest and significance were the observa. tions of the swelling of the soil due to impregnation by water after filling the dam, made by Farnsworth (Australia), on the Nepean Dam, and by André Nizery (of France) on the Sautet and Querlédan Dams.

The phenomenon of piping and seepage provided the subject for fifteen papers in the third group. A dam may fail by piping in two different ways : either the seepage pressure exerted by the percolating water may cause a failure of the soil beneath the dam; or the soil may be removed from beneath the dam by 